\title{
FAKTOR-FAKTOR YANG MEMPENGARUHI PENEGAKAN STANDAR DIAGNOSA KEPERAWATAN
}

\author{
EBIAL FITRI BR GINTING \\ ebyalfitriginting@gmail.com
}

\section{Latar Belakang}

Diagnosis keperawatan merupakan penilaian klinis terhadap pengalaman atau respon individu, keluarga, dan komunitas pada masalah kesehatan pada resiko masalah kesehatan atau pada proses kehidupan. Diagnosis keperawatan merupakan bagian vital dalam menentukan asuhan keperawatan yang sesuai untuk membantu klien mencapai kesehatan yang optimal. Mengingat pentingnya diagnosis keperawatan dalam memberian asuhan keperawatan, maka dibutuhkan standar diagnosis keperawatan yang dapat diterapkan di Indonesia. Faktor Perumusan diagnosa keperawatan membutuhkan proses berpikir kritis, keterampilan penalaran serta pengalaman sebelumnya. Penyusunan format diagnosa keperawatan standar yang sedang dilakukan saat ini menggunakan pendekatan standar NANDA. Diagnosis keperawatan dibuat berdasarkan hasil pengkajian yang diterapkan oleh perawat sesuai dengan apa yang tertuang dalam format pengkajian. Diagnosis keperawatan dibuat berdasarkan hasil pengkajian yang diterapkan oleh perawat sesuai dengan apa yang tertuang dalam format pengkajian.

Diagnosis keperawatan harus ditingkatkan lagi didalam dipelayanan rumah sakit dan fasilitas kesehatan lainnya agar seragam, akurat, dan tidak ambigu. Penegakan diagnosis keperawatan sebagai salah satu komponen standar asuhan keperawatan perlu dilaksanakan dengan baik sebagaimana yang diamanahkan dalam undang-undang No.38 tahun 2014 tentang keperawatan pada pasal 30 bahwa dalam menjalankan tugas sebagai pemberi asuhan keperawatan, perawat berwenang menetapkan diagnosis keperawatan. Perawat sebagai penegak diagnosis yang harus memiliki kemampuan diagnosis yang baik sebagai dasar mengembangkan rencana intervesnsi keperawatan 
dalam mencapai peningkatan, pencegahan, penyembuhan dan pemulihan kesehatan klien.

Metode

Metode yang digunakan adalah metode kualitatif dimana maksudnya dengan cara mengumpulkan sebanyak-banyaknya data untuk dianalisis. Yaitu dengan Literature review ini dengan menganalisis yang berfokus pada faktor faktor yang mempengaruhi penegakan standar diagnosa keperawatan. Adapun tinjauan literatur yang digunakan seperti buku teks, buku referensi, jurnal, dan google scholar. Dengan kata kunci penegakan, standar, dan diagnosa keperawatan. Dan yang digunakan adalah 10 literatur yang diterbitkan 10 tahun terakhir.

Hasil

Penegakan diagnosis keperawatan sebagai salah satu komponen standar asuhan keperawatan perlu dilaksanakan dengan baik sebagaimana yang diamanahkan dalam undang-undang No.38 tahun 2014 tantang keperawatan pada pasal 30 bahwa dalam menjalankan tugas sebagai pemberi asuhan keperawatan, perawat berwenang menetapkan diagnosis keperawatan. Perumusan diagnosa keperawatan yakni bagaimana diagnosa keperawatan digunakan dalam proses pemecahan masalah. Melalui identifikasi, bisa digambarkan berbagai masalah keperawatan yang membutuhkan asuhan keperawatan.Salah satu kompetensi perawat bisa merumuskan diagnose keperawatan yang baik dan benar, dimana diagnosa keperawatan adalah kesimpulan yang dihasilkan dari analisis data, sehingga menghasilkan pernyataan yang jelas, singkat dan pasti tentang masalah pasien. Hasil ini meliputi bagaimana perencanaan dalam keperawatan. Dari hasil ini kita bisa mengetahui pentingnya perawat membuat perencanaan asuhan keperawatan dengan benar dan tepat.

\section{Pembahasan}

Diagnosis keperawatan merupakan penilaian klinis terhadap pengalaman atau respon individu, keluarga, dan komunitas pada masalah kesehatan pada resiko masalah kesehatan atau pada proses kehidupan. Diagnosis keperawatan merupakan bagian vital 
dalam menentukan asuhan keperawatan yang sesuai untuk membantu klien mencapai kesehatan yang optimal. Mengingat pentingnya diagnosis keperawatan dalam memberian asuhan keperawatan, maka dibutuhkan standar diagnosis keperawatan yang dapat diterapkan di indonesia.

Penegakan diagnosis keperawatan sebagai salah satu komponen standar asuhan keperawatan perlu dilaksanakan dengan baik sebagaimana yang diamanahkan dalam undang-undang No.38 tahun 2014 tantang keperawatan pada pasal 30 bahwa dalam menjalankan tugas sebagai pemberi asuhan keperawatan, perawat berwenang menetapkan diagnosis keperawatan. Hal ini menegaskan wewenang perawat sebagai penegak diagnosis yang harus memiliki kemampuan diagnosis yang baik sebagai dasar mengembangkan rencana intervensi keperawatan dalam rangka mencapai peningkatan, pencegahan dan penyembuhan serta pemulihan kesehatan klien.

Sebuah studi yang dilakukan di Indonesia menunjukkan bahwa $50 \%$ bentuk penilaian keperawatan tidak mengandung informasi lengkap. Sebagian besar dokumen proses keperawatan tidak lengkap, karena persepsi bahwa formulir keperawatan tidak sesuai untuk mendokumentasi kan kebutuhan perawatan pasien. melaporkan bahwa proses dokumentasi tidak mampu menangkap informasi dari diagnosis keperawatan. Studi ini menunjukkan bahwa sedikit atau tidak ada usaha yang dilakukan untuk mengabungkan formulir penilaian dengan diagnosis keperawatan, serta penerapan diagnosis keperawatan di Indonesia. Dokumentasi keperawatan menyita hampir 50\% waktu perawat pershift kebanyakan perawat dalam urutan klinis, tidak melakukan dokumentasi yang lengkap. Alasan mengapa perawat tidak melakukan dokumentasi keperawatan adalah kebanyakan perawat lebih memilih meluangkan waktu untuk melakukan tindakan pada pasien dan tidak mendokumentasikannya. Faktor pekerjaan, pelatihan dan beban kerja. Merupakan faktor yang dapat mempengaruhi kelengkapan dokumentasi keperawatan. Lingkungan kerja, beban kerja yang tinggi, dan sulitnya dokumentasi format waktu pengisian berkontribusi terhadap kurangnya dokumentasi keperawatan.

Standar Diagnosis Keperawatan Indonesia (SDKI) merupakan tolak ukur atau acuan yang digunakan sebagai pedoman dasar penegakan diagnosis keperawatan 
dalam rangka memberikan asuhan keperawatan yang aman, efektif dan etis (PPNI, 2017). SDKI diterbitkan oleh PPNI pada tanggal 29 Desember 2016. Latar belakang penyusunan SDKI yakni masih belum tersedia standar diagnosis keperawatan yang mempertimbangkan nilai budaya serta ciri khas masyarakat Indonesia.

Diagnosis keperawatan yang ditegakkan berdasarkan pengkajian NANDA-ISDA lebih beragam daripada diagnosis keperawatan yang ditegakkan oleh perawat. Dengan NANDAISDA pengkajian dilakukan dari berbagai aspek serta didasari pada pemahaman terhadap definisi suatu diagnosis tersebut. Sedangkan diagnosis yang dibuat perawat tidak didasari kepada pengkajian serta pemahaman tentang definisi diagnosis itu sendiri, contohnya terdapat diagnosis "Gangguan pola tidur". Istilah ini tidak ditemukan dalam nomenklatur NANDA-I, untuk data kurang tidur. Namun data " kurang tidur " akan memunculkan diagnosis "Risiko jatuh". Begitu pula, tidak satupun masalah kolaborasi (potensial complication) ditegakkan oleh perawat sementara dari rutinitas pekerjaan yang dilakukan lebih banyak pada pekerjaan mengatasi masalah pontensial komplikasi. Diagnosa keperawatan ditegakkan berdasarkan respon fisik, sosio-kultural, psikologis, serta spiritual klien terhadap masalah kesehatannya yang bersifat individual, sehingga diperlukan kemampuan berpikir kritis dalam proses diagnostik. Penegakkan diagnosa keperawatan harus didukung sekelompok data dasar yang didapatkan oleh perawat pada saat melakukan pengkajian. Kelompok data ini disebut batasan karakteristik. Batasan karakteristik adalah indikator klinis yang berupa tanda dan gejala objektif ataupun subjektif maupun faktor risiko yang mendukung adanya kategori diagnostik. Indikator klinis yang akurat diperlukan agar memvalidasi diagnose keperawatan yang ditegakkan. Keakuratan indikator klinis ditentukan dengan kemunculan batasan karakteristik serta faktor yang berhubungan (etiologi) dari suatu diagnosa keperawatan.

Faktor - faktor Perumusan diagnose keperawatan membutuhkan proses berpikir kritis,keterampilan penalaran serta pengalaman sebelumnya. Penyusunan format diagnosa keperawatan standar yang sedang disusun saat ini menggunakan pendekatan standar NANDA. Tim penyusun terdiri dari kepala ruang, supervisor serta manajemen keperawatan dengan latar belakang pendidikan dan pengalaman kerja di bidang 
keperawatan. Perawat sepakat bahwa tipe checklist mudah diaplikasikan jika format diagnosa keperawatan yang baru nanti tersusun. Checklist ini merupakan salah satu metode pengamatan terstruktur di mana sebelumnya secara cermat telah mendefinisikan apa yang akan diobservasi melalui suatu perencanaan yang matang.

Kategori Diagnosa Keperawatan Diagnosa keperawatan bisa dibedakan menjadi 5 kategori: Aktual, Resiko, Kemungkinan, Keperawatan welness, Keperawatan Sindrom.

Diagnosis Keperawatan adalah keputusan klinik tentang respon individu, keluarga serta masyarakat tentang masalah kesehatan aktual maupun potensial, dimana berdasarkan pendidikan serta pengalamannya, perawat secara akuntabilitas bisa mengidentifikasi dan memberikan intervensi secara pasti untuk menjaga, menurunkan, membatasi, mencegah dserta merubah status kesehatan klien. Untuk dapat merumuskan diagnose keperawatan dibutuhkan kemampuan analisis yang tinggi sehingga diperlukan sumber daya manusia yang capable serta mempunyai motivasi kuat agar maju serta berpandangan maju (futuristic). Pada status pasien yang telah dikaji terlihat bahwa perawat hanya memilih saja diagnose keperawatan yang sudah disediakan di bagian samping format pengkajian. Hal ini memang lebih memudahkan perawat namun juga dapat menyebabkan perawat menjadi malas serta kurang inisiatif untuk menganalisa data lalu merumuskan diagnose keperawatan sendiri apabila ditemukan data yang berbeda. Kondisi demikian juga menimbulkan kualitas pendokumentasian diagnosa keperawatan menjadi monoton.

Penutup

Diagnosis keperawatan merupakan penilaian klinis terhadap pengalaman atau respon individu, keluarga, dan komunitas pada masalah kesehatan pada resiko masalah kesehatan atau pada proses kehidupan. Diagnosis keperawatan merupakan bagian vital dalam menentukan asuhan keperawatan yang sesuai untuk membantu klien mencapai kesehatan yang optimal. Mengingat pentingnya diagnosis keperawatan dalam memberian asuhan keperawatan, maka dibutuhkan standar diagnosis keperawatan yang dapat diterapkan di indonesia. Penegakan diagnosis keperawatan sebagai salah satu komponen standar asuhan keperawatan perlu dilaksanakan dengan baik 
sebagaimana yang diamanahkan dalam undang-undang No.38 tahun 2014 tentang keperawatan pada pasal 30 bahwa dalam menjalankan tugas sebagai pemberi asuhan keperawatan, perawat berwenang menetapkan diagnosis keperawatan. Perawat sebagai penegak diagnosis yang harus memiliki kemampuan diagnosis yang baik sebagai dasar mengembangkan rencana intervesnsi keperawatan dalam mencapai peningkatan, pencegahan, penyembuhan dan pemulihan kesehatan klien.

\section{Daftar Pustaka}

Rachmania, D., Nursalam., Yunitasari, E. (2016). Pengembangan instrument diagnosis \& intervensi keperawatan berbasis standardized nursing language (NANDA, NOC, NIC). Jurnal Ners Vol 11 (2) Hal 157-163.

Made Ermayani, Aprilia Nuryanti.(2017). Pengembanagn format dokumentasi asauhan keperawatan berbasis standardized nursing language (SNL) NANDA-I,NOC.Mahakam nursing journal .Vol 2,No 2

Yanti, R. I., \& Warsito, B. E. (2013). Hubungan Karakteristik Perawat, Motivasi dan Supervisi dengan Kualitas Dokumentasi proses Asuhan Keperawatan. Jurnal Manajemen Keperawatan. Volume 1, No.2, November 2013; 107-114.

Hidayah, Nur (2014). Manajemen Model Asuhan Keperawatan Profesional (MAKP) Tim Dalam Peningkatan Kepuasan Pasien Di Rumah Sakit. Jurnal Kesehatan Vol 1. No. 2; 410-426.

Cikwanto , Nupiyanti. (2018). Pengembangan Instrumen Penegakan Diagnosis Keperawatan Pada Pasien Congestive Heart Failure (CHF) Berbasis Standar Diagnosis Keperawatan Indonesia (SDKI). Jurnal Keperawatan 'AISYIYAH, 5(1), 51-63.

Aprisunadi. (2017). Standar Diagnosis Keperawatan Indonesia. Jakarta: Dewan Penggurus Pusat Persatuan Perawat Nasional Indonesia. 
Mogopa, C. P., Pondaag, L.,\& Hamel, R. S. (2017). Hubungan Penerapan Metode Tim dengan Kinerja Perawat Pelaksana di Irina C RSUP Prof. Dr. R. D. Kandou Manado. EJournal Keperawatan (e-Kp) Vol 5 (1).

Kusnadi. Elon. (2017). Analisis Kelengkapan Dokumentasi Keperawatan di Ruang Rawat Inap Non Intensive Rumah Sakit X. Jurnal Bidang Ilmu Kesehatan, 9(1), 553-561.

Ulum, Muh. Miftahul dan Wulandari, Ratna D. (2013). Faktor yang Mempengaruhi Kepatuhan Pendokumentasian Asuhan Keperawatan Berdasarkan Teori Kepatuhan Milgram. Jurnal Administrasi Kesehatan Indonesia,Vol.1(3), 252-262

Santoso. R. Arief. (2018). Hubungan Pengetahuan dan Motivasi Perawat Dengan Kinerja Pendokumentasian Asuhan Keperawatan di Pelayanan Rawat Inap Puskesmas Guluk Guluk .Jurnal Ilmu Kesehatan, 3(1), 10-19.

Simamora, R. H., Bukit, E., Purba, J. M., \& Siahaan, J. (2017). Penguatan kinerja perawat dalam pemberian asuhan keperawatan melalui pelatihan ronde keperawatan di rumah sakit royal prima medan. Jurnal pengabdian kepada masyarakat, 23(2),300-304.

Simamora, R. H. (2019). Socialization of Information Technology Utilization and Knowledge of Information System Effectiveness at Hospital Nurses in Medan, North Sumatra. Editorial Preface From the Desk of Managing Editor 10(9). 